\title{
Analisis Gaya Kepemimpinan Partisipatif di Perpustakaan Universitas Bunghatta Sumatera Barat
}

\author{
Septevan Nanda Yudisman \\ Konsentrasi IImu Perpustakaan dan Informasi, Pascasarjana UIN Sunan Kalijaga Yogyakarta \\ email: septevannanda@gmail.com
}

\begin{abstract}
The leader is the glue in the organization, he must be able to think and think about the organization, support organizations such as libraries that are approved by two factors, namely the way to lead and policies in leadership. Organizations that are not advanced determine an ineffective leadership style. They cannot defeat their subordinates. The participatory leadership style emphasizes support decisions in making decisions and policies with little direction. A good leadership factor will be a control of problem solving in an organization. Democratic leadership at BungHatta University can encourage librarian performance and motivate them to achieve with input support from all parties who support and subordinate
\end{abstract}

\begin{abstract}
Abstrak
Pemimpin adalah perekat dalam organisasi, ia harus mampu berpikir holistik serta mampu memegang kendali organisasi, keberhasilan sebuah organisasi seperti perpustakaan dipengaruhi oleh dua fakor yaitu cara memimpinnya dan kebijakan dalam memimpin. Organisasi yang tidak maju disebabkan akan gaya kepemimpinan yang tidak efektif. Mereka tidak mampu memimpin bawahannya. Gaya kepemimpinan partisipatif lebih menekankan pada tingginya dukungan dalam pembuatan keputusan dan kebijakan dengan sedikit pengarahan. Faktor kepemimpinan yang bagus akan menjadi kontrolitas pemecahan masalah dalam sebuah organisasi. Kepemimpinan demokrasi di Universitas BungHatta bisa mendorong kinerja pustakawan dan memotivasi meraka untuk berprestasi dengan mendengarkan masukan dari segala pihak baik itu pimpinan dan bawahan.
\end{abstract}

Keywords:

Leader

organization

leadership style

participatory

BungHatta University

Kata Kunci:

Pemimpin,organisasi,gaya

kepemimpinan,par

tisipatif,Universitas

BungHattaUniversity

\section{A. PENDAHULUAN}

Dalam setiap organisasi akan memiliki struktur kepemimpinan, organisasi yang kurang efektif kepemimpinannya maka akan menimbulkan konflik dalam organisasi tersebut maka kepemimpinan yang baik akan mencapai tujuan individu, kelompok dan organisasi yang baik (Husaini, 2011). Pemimpin merupakan perekat dalam organisasi. la harus mampu berpikir holistik dan memegang struktur organisasi (Tikno, 2013). Setiap pemimpin hendaknya memiliki visi dan misi untuk mencapai tujuan suatu organisasi . Selain itu atasan juga harus bersemangat, dan daya dorong atau energy yang besar untuk mencapai visinya.

Kedudukan suatu perpustakaan dipengaruhi oleh gaya kepemimpinan dalam perpustakaan.
Sebaliknya kegagalan organisasi manapun itu dipengaruh oleh gaya kepemimpinan yang tidak efektif, maka tidak mampu memimpin bawahannya,tidak mampu mendorong kerja berkelompok dan tidak mampu mengendalikan diri sendiri, dengan demikian organisasi tidak berjalan secara efektif.

Seorang pemimpin seharusnya memiliki karakter yang melekat didalam kepribadiannya memiliki integritas dan kapabilitas kepemimpinan. Bentuk kapabilitas seorang pemimpin terlihat pada kemampuan menggerakan. maka pemimpin harus mampu mengkonsolidasikan bawahannya antara lain dalam bentuk perintah, paksaan, otoritas, himbauan dan lain-lain-lain. menurut Jhon C. Macwell sifat kepemimpinan adalah bisa 
mempengaruhi bawahannya (Tikno, 2013). Gaya kepemimpinan merupakan faktor penting yang akan mempengaruhi prestasi bawahan. Salah satu faktor penting yang mempengaruhi proses kepemimpinan adalah gaya kepemimpinan.

Nawawi mengungkapkan (Nawawi \& Hadari, 2004) sifat kepemimpinan hendaknya dipergunakan untuk mempengaruhi bawahannya. Sementara Mathis (Mathis \& Jackson, 2003) mendefenisikan sifat atasan sebagai cara seorang pemimpin adalah mempengaruhi perilaku bawahan, agar mau bekerja sama dan bekerja secara produktif untuk mecapai gaya organisasi yang diinginkan. Dalam banyak gaya kepemimpinan disini peneliti akan meneliti gaya kepemimpinan Partisipatif di Perpustakaan Universitas Bung Hatta Sumatera Barat.

Sifat kepemimpinan demokratis hendaknya menitikberatkan kepada pembuatan keputusan yang terbuka dan ditujukan untuk memecahkan masalah bersama dalam organisasi. Kepala perpustakaan serta para pustakawan akan bertukar pikiran dalam memecahkan konflik yang dihadapi. Dengan demikian, pustakawan yang memiliki kemampuan lebih merasa dihargai dan bisa mengusulkan ide-ide yang cemerlang dan bisa diikutsertakan dalam proses pembuat keputusan demi memajukan perpustakaan perguruan tinggi.

Tujuan penulisan artikel ini adalah untuk melihat fenomena menarik untuk dikaji bahwa gaya kepemimpinan partisifatif apakah mampu untuk mengembangkan dan memajukan perkembangan perpustakaan Universitas Bung Hatta Sumatera Barat.

\section{B. KAJIAN TEORITIS}

\section{Defenisi Perpustakaan}

Seiring dengan perkembangan ilmu pengetahuan,saat ini perpustakaan sudah bertransformasi sebagai sumber informasi. Perpustakaan yang telah dibicarakan dalam berbagai sumber, dalam Undang-Undang Nomor
43 tahun 2007 menyebutkan bahwa Perpustakaan yaitu suatu institusi pengelola karya tulis, karya cetak, dan/atau karya rekam secara professional dengan sistem yang baku guna memenuhi kebutuhan pendidikan, penelitian, pelestarian, informasi, dan rekreasi para pemustaka.

Perpustakaan saat ini mempunyai peran penting sebagai penyedia informasi. Perpustakaan saat ini tidak lagi dalam bentuk yang kaku dimana perpustakaan harus memberikan pelayanan yang informasinya dapat diakses yang tidak terbatas dengan ruang dan waktu. Perpustakaan saat ini harus mampu menyediakan informasi dalam berbagai media baik secara nyata maupun maya yang informasinya dapat diakses kapan dan dimana saja.

Menurut ahli perpustakaan adalah suatu sistem informasi yang dalam kegiatannya terdapat aktivitas pengumpulan, pengolahan, pengawetan, pelestarian dan penyajian (HS, 2009).

Perpustakaan merupakan institusi yang bergerak sebagai layanan . menurut Barata perpustakaan harus sebagai penyedia layanan (Service provider) dalam organisasi yang memberikan suatu layanan tertentu kepada konsumen baik berupa layanan dalam bentuk penyediaan jasa (service) (Brata, 2003).

\section{Perpustakaan Perguruan Tinggi}

Organisasi perpustakaan di perguruan tinggi merupakan hal yang mutlak adanya karena perpustakaan di perguruan tinggi adalah pusat informasi yang digunakan oleh setiap sivitas akademik di perguruan tinggi (Basuki, 2010). Organisasi suatu perpustakaan perguruan tinggi merupakan bagian yang tidak terpisahkan dari struktur perguruan tinggi yang mencakup perpustakaan pusat, perpustakaan fakultas dan lain-lain. Begitu pentingnya perpustakaan ini untuk mencapai pelayanan yang baik untuk menyediakan informasi untuk tercapainya tri dharma perguruan tinggi. 
a. Tujuan Perpustakaan Perguruan Tinggi

Kampus atau perguruan tinggi merupakan pusat dari proses penelitian yang menyediakan informasi yang dibutuhkan oleh sivitas akademik di universitas, maka tujuan dari perpustakaan perguruan tinggi sebagai berikut:

1). Mengadakan bahan informasi seperti jurnal dan mengadakan buku-buku sesuaikebutuhan oleh sivitas akademik suatu perguruan tinggi.

2). Mengupayakan pengadaan bahan informasi sesuai dengan dana yang tersedia.

3). Tugas untuk merawat bahan informasi yng bernilai sejarah yang dihasilkan sivitas akademika.

4). Mengadakan bibliografi untuk meningkatkan peminjaman di perpustakaan serta menyediakan pustakawan yang berdedikasi tinggi dalam melakukan pelayanan bagi pemustaka.

5). Menjalin hubungan dan kerja sama dengan perpustakaan universitas lain.

Berdasarkan penjelasan di atas, dapat dilihat tujuan perpustakaan adalah sebagai penyedia jasa pelayanan informasi meliputi pengumpulan, pelestarian, pengolahan Fungsi Perpustakaan Perguruan Tinggi

b. Fungsi dari perpustakaan perguruan tinggi Fungsi perpustakaan perguruan tinggi dapat dilihat:

1). Perpustakaan berfungsi sebagai tempat belajar karena adanya koleksi yang dibutuhkan pemustaka.

2). Perpustakaan berfungsi sebagai sumber informasi berbagai bidang.

3). Perpustakaan berfungsi sebagai saran pendukung dalam penelitian, karena bahan infomasi yang dikelola perpustakaan sangat membantu dalam proses penelitian

4). Perpustakaan memiliki fungsi sebagai rekreasi pemustaka karena tersedianya bahan rekreasi di perpustakaan.
5). Perpustakaan juga berfungsi sebagai media mempuplikasi bagi peneliti yang ingin karyanya dipuplikasikan.

6). Untuk mengkaji dan memberikan nilai tambah dalam hal penyedia informasi di perguruantinggi (Sjahrial-Pamuntjak, 2000).

\section{Defenisi Kepemimpinan}

Pemimpin harus memliki sifat kepemimpinan untuk dapat mempengaruhi bawahan atau pegawainya sehingga tujuan dari organisasi bisa dicapai dengan baik, sesuai dengan harapan organisasi.

Fiedler mengemukakan kepemimpinan merupakan suatu hubungan indvidu yang menggunakan wewenang dan pengaruhnya terhadap kelompok individu untuk bisa mencapai tujuan (Rivai, 2013). Menurut Ott yang dikutip oleh Rivai dkk mengemukakan kepemimpinan dapat didefenisikan sebagai proses hubungan antar pribadi yang dapat mempengaruhi hubungan kepercayaan dan perilaku kepemimpinan wanita atau Feminist Leadership memiliki ciri-ciri berikut (G, 1997):

a. Menggunakan konsensus dalam pengambilan keputusan

b. Menunjukkan kekuatan relasional

c. Mendahulukan pendekatan-pendekatan yang produktif terhadap konflik

d. Membangun suasan kerja yang saling mendukung.

\section{Teori Kepemimpinan}

Menurut Kartono (Kartono, 2006) teori sifat kepemimpinan adalah sifat individu yang sesuai dengan konsep-konsep kepemimpinan yang melekat kepada sifat pribadinya dan sesuai dengan sejarah dan latar belakang individu tersebut serta bisa memenuhi tugas pokok dalam menjalankan kepemimpinannya bisa dilihat dengan teori kepemimpinan yakni: 
a. Sifat,sesuai dengan penjelasan teorinya berguna untuk mengidentifikasi karakter baik secara fisik maupun kepribadian. Oleh karena itu pemimpin yang baik akan memiliki keunggulan secara fisik dan kepribadian yang tenang menghadapai masalah dan bijaksana pengambilan keputusan.

b. Kepemimpinan berdasarkan perilakunya akan sesuai dengan kualitas pribadi dan pola kelakuannya Dalam hal ini kepemimpinan tidak akan melakukan tindakan yang sama dengan setiap kondisi yang dialaminya

c. Dalam situasi tertentu pemimpin akan dapat dengan cepat memahami tindakan yang akan diambil untuk bahawannya dan bisa tanggap mengerti tentang bawahannya

Terry dalam Katono mengemukakan kepemimpinan, yaitu: teori otokratis, teori psikologi, teori sosiologis, teori suportif/partisifatif, teori laisses faire, teori kelakuan pribadi, teori sifat orang besar, teori situasi, teori humanistic/populastik.

\section{Gaya Kepemimpinan Partisipatif}

Perilaku kepemimpinan adalah sifat yang bisa digunakan untuk bisa mempengaruhi orang lain yang disebut bawahan dan dapat menyeleraskan kemauanya untuk mengarahkan bawahan tersebut untuk mencapai tujuan.

Dalam kepemimpinan partisipatif hendaknya bisa melibatkan bawahan untuk membuat keputusan organisasi secara bersama. Hal ini penting untuk mengeluarkan pemikiran-pemikiran kreatif bawahan dalam pemecahan permasalahan dalam organisasi dan bisa mencapai tujuan organisasi.

Karakteristik gaya kepemimpinan yang beranekaragam dapat mempengaruhi sikap bawahan peranan itu sebagai berikut:

1. Mempunyai keaktifan dalam organisai

2. Dapat mengutamakan kepentingan kegiatan.

3. Mampu untuk bekerjasama dalam setiap hubungan kelompok di organiasi lainya.

4. Membuat hubungan yang baik antara staf dalam organisasi

5. Bisamembuatkeuntungandalamhubungan kelompok didalam tubuh organisasi.

6. Mencontohkan teknik pelaksanaan program organisasi terhadap bawahannya.

Dengan uraian diatas dapat disimpulkan bahwa sifat kepemimpinan adalah suatu kemauan dan kemampuan seseorang dalam mengarahkan serta mempengaruhi bawahannya serta mendorong bawahan untuk bisa bekerja atas inisiatif sendiri tanpa paksaan dalam mencapai tujuan organisasi.

\section{METODE PENELITIAN}

Penelitian ini akan menggunakan pendekatan kualitatif deskriptif. Penulis melakukan ini karena terdapat beberapa hal yang memerlukan penyelidikan secara langsung terhadap informan. Menurut Jane Richie penelitian kualitatif adalah upaya untuk menyajikan dunia sosial dan perspektifnya di dalam dunia, dari segi konsep, perilaku, dan persoalan, tentang manusia yang diteliti (Lexi, 2008).

\section{HASIL DAN PEMBAHASAN}

Pada pembahasan ini peneliti akan menyajikan data hasil yang peneliti peroleh dari hasil wawancara dengan narasumber secara mendalam. Disini penulis akan mengenalkan secara singkat yang merupakan narasumber dari penelitian ini yaitu bernama Ahmad elzuri merupakan staf dari Perputakaan Universitas Bunghatta yang juga lulusan Sarjana ilmu perpustakaan dari Universitas sumatera Utara. Data dari pustakawan ini dapat penulis sampaikan dengan judul Analisis Gaya Kepemimpinan Partisipatif di Perpustakaan Universitas Bunghatta Sumatera Barat,wawancara pada penelitian ini dilaksanakan pada tanggal 18 desember 2018.berikut hasil dari penelitian penulis 
yaitu :

1. Bagaimanakah gaya kepemimpinan di perpustakaan Universitas BungHatta?

Narasumber : Gaya kepemimpinan di Perpustakaan Universitas BungHatta menurut pengalaman saya memberikan ruang kepada bawahannya untuk memberikan masukan dan menerima kritik yang membangun serta dalam setiap penyelesaian permasalahan yang ada selalu didiskusikan jalan keluarnya jadi sangat partisipatif atau demokratis.

2. Apakah jadwal diskusi ditentukan atau kalau ada masalah baru di diskusikan?

Narasumber: Untuk jadwal tiap awal bulan sudah dijadwalkan untuk ada diskusi tapi kalau ada masalah yang patut diselesaikan cepat biasanya hari itu juga didiskusikan.

3. Bagaimana motivasi kerja pustakawan dengan gaya kepemimpinan partisipatif tersebut?

Narasumber : dengan gaya yang terbuka tersebut kami mempunyai motivasi yang bangus dengan bekerja lebih giat dan disiplin serta lebih terbuka terhadap atasan dalam menyampaikan pendapat,kritikan dan saran untuk kemajuan perpustakaan.

4. Bagaimana hubungan pustakawan dengan motivasi kerja terhadap gaya kepemimpinan partisipatif tersebut?

Narasumber : hubungan kami dengan atasan lebih dekat lagi karena pimpinan menghargai masukan dan pendapat kami serta mau mendengarkan keluhan kami. Serta motivasi kami adalah dengan lebih disiplin dan giat karena peraturan kinerja kami yang sepakati sendiri dengan pimpinan.

5. Apakah dengan gaya kepemimpinan partisipatif tersebut masih ditemukan kendala teknis dalam kinerja?

Narasumber : dengan hungungan yang terbuka kami dengan pimpinan biasanya kalau ada masalah yang kompleks sekali biasanya kami langsung diadakan rapat untuk mencari jalan keluar dan pimpinan sangat suka dengan itu biar kinerja kami cepat diselesaikan.

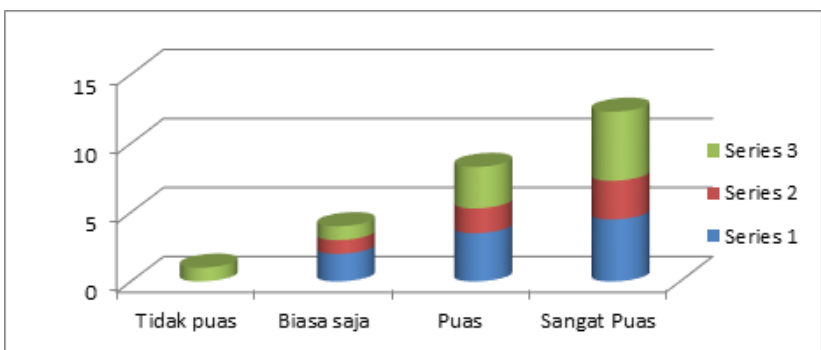

Grafik kepuasan pustakawan terhadap kepemimpinan Partisipatif

Dari hasil wawancara tersebut dapat disimpulkan bahwa gaya kepemimpinan partisipatif di Universitas BungHatta bisa mendorong kinerja pustakawan menjadi lebih baik serta motivasi pustakawan untuk kinerja yang baik lebih meningkat dan setiap permasalahan yang ada di perpustakaan langsung diselesaikan dengan cepat dengan mendengarkan masukan dari segala pihak baik itu pimpinan dan bawahan.

\section{E. PENUTUP}

\section{Simpulan}

Sesuai dengan laporan penelitian yang sudah dilakukan maka disini penulis dapat menyimpulkan yaitu :

1. Gaya kepemimpinan di Universitas Bung Hatta Padang Sumatera Barat adalah gaya kepemimpinan parsitipatif dengan menerima masukan dan kritikan dari bawahannya.

2. Dengan gaya kepemimpinan yang partisipatif tersebut maka dapat meningkatkan motivasi kerja pustakawan di Universitas BungHatta.

3. Saling kepercayaan antara pimpinan dan bawahan dengan menerima masukan dan kritikan dengan cara diskusi maka akan menjadi kekuatan yang penting untuk menjalakan kinerja pustakawan yang baik dan 
terampil.

4. Pemecahan masalah yang langsung dibicarakan akan membuat penghambat kinerja bisa diatasi secepat mungkin supaya tidak mengganggu kinerja perpustakaan yang lainnya.

\section{Saran}

Berdasarkan hasil penelitian dan pembahasan yang telah dilakukan dalam penelitian ini maka penulis memberikan saran yaitu :

1. Perpustakaan Universitas BungHatta selalu terbuka dalam kebijakan perpustakaan dan menampung setiap aspirasi pustakawan dalam memberikan kritikan serta masukan untuk optimalnya kinerja pustakawan.

2. Pustakawan hendaknya selalu memberikan masukan yang membangun kepada pimpinan untuk mencapai kinerja yang baik.

3. Pimpinan dan pustakawan hendaknya membuat diskusi yang berkelanjutan dalam memecahkan setiap permaalahan yang ada diperpustakaan.

\section{DAFTAR PUSTAKA}

Basuki, S. (2010). Pengantar Ilmu Perpustakaan. Jakarta: Gramedia Pustaka Utama.

Brata, A. A. (2003). Dasar-dasar Pelayanan Prima. Jakarta: Elex Media Komputindo.

G, N. P. (1997). Leadership Theory and Practice. London: Sage Publication.

HS, L. (2009). Kamus Kepustakawanan Indonesia (1st ed.). Yogyakarta: Pustaka Book Publisher.

Husaini, U. (2011). Manjemen: Teori, Praktik, dan riset pendidika. Jakarta: Bumi Aksara.

Kartono, K. (2006). pemimpin dan kepemimpinan. Jakarta: Raja Grafindo Persada.

Lexi, M. J. (2008). Metodelogi penelitian kuanlitatif. Bandung: Rosda.

Mathis, R., \& Jackson, J. (2003). Manajemen Sumber daya Manusia. Jakarta: Salemba.

Nawawi, H., \& Hadari, M. M. (2004). Kepemimpinan yang efektif. Yogyakarta: Gadjah Mada UniversityPress.

Rivai, V. (2013). Pemimpin dan kepemimpinan dalam organisasi. Jakarta: Raja Grafindo Persada.

Sjahrial-Pamuntjak, R. (2000). Pedoman Penyelenggaraan Perpustakaan. Jakarta: Djambatan.

Tikno, L. (2013). Leadership untuk Profesional dan Mahasiswa. Surabaya: Erlangga. 